\title{
A Citizen's Guide to the Second Amendment
}

\author{
D. L. Womble
}

$\mathbf{N}$

ow-when a new generation is poised to enter the fray of the American debate over the meaning of the Second Amendment and how we might control the possession and use of firearms in our country-a review of the evolution of the firearms debate through the prism of historical documents, congressional debate and legislation, regulations by federal agencies, and statistical data seems useful. Such an undertaking is daunting and can never be exhaustive; yet, if we are to have a substantive conversation and find a reasonable path forward, citizens need to be armed with information.

A rational conversation will be rooted in fact; thus, the participants' knowing the evolution of this debate is critical. This guide makes this information easily accessible from one place, using natural language. While crafted for the novice researcher, the guide also aspires to be useful to veteran scholars. The result is a collection of freely accessible resources provided by the federal government and other reliable secondary sources that offers an overview of the history of federal firearms laws and insight into the debate surrounding Second Amendment rights and sensible gun control measures.

A secondary goal of this guide is to show citizens the myriad official, online resources (and a few unofficial ones) through which our federal government can be explored. The guide is presented in two parts: (1) a chronology of firearms legislation generated by the three branches of the federal government and (2) a research guide to the Second Amendment.

\section{The Second Amendment Legacy}

Our federal firearms laws take three forms and come from the three branches of government. The US Congress enacts statutes (laws) that then become part of the U.S. Code and the law of the land. The federal courts interpret the statutes through their opinions on individual cases, and these opinions are known as case law. The president and the executive branch apply the laws through rules and regulations. So, there are statutes, case law, and administrative regulations that have all interpreted the Second Amendment. Here are the significant firearms laws in the United States from the adoption of the Second Amendment to the present:

1791 The Bill of Rights consisting of the first ten amendments to the US Constitution is ratified (approved) by the thirteen states. The Second Amendment states, "A well-regulated Militia, being necessary to the security of a free State, the right of the people to keep and bear Arms, shall not be infringed."

1876 The US Supreme Court rules in United States v. Cruikshank that the Second Amendment "has no other effect than to restrict the powers of the national government" and holds that the Second Amendment creates no individual right to keep or bear arms. ${ }^{2}$

1886 In Presser v. Illinois, the US Supreme Court states that the Second Amendment "is a limitation only upon the power of Congress and the National government, and not upon that of the States."

1894 In Miller v. Texas, the US Supreme Court affirms that the Second Amendment limits the federal government's power and not the individual states. ${ }^{4}$

1897 In Robertson v. Baldwin, the US Supreme Court reinforces the notion that the Second Amendment limits the Congress but not state legislatures. ${ }^{5}$

1934 Congress makes its first effort to restrict the use of firearms by enacting The National Firearms Act (NFA) after the St. Valentine's Day Massacre of 1929 and the attempted assassination of President Franklin D. Roosevelt in 1933. The NFA levies taxes on persons and companies that import, manufacture, and sell firearms and requires that all firearms be registered with the Secretary of the Treasury. Firearms defined by this law include shotguns and rifles with barrels less than eighteen inches 
long, machine guns, and firearms described as "any other weapons," along with mufflers and silencers. The sale of the handguns of the era-pistols and revolversare not taxed, and they do not have to be registered. ${ }^{6}$

1938 The Federal Firearms Act of 1938 requires gun sellers to be licensed by the Internal Revenue Service to sell guns and to maintain records of purchases, and it prohibits felons from purchasing firearms or ammunition. ${ }^{7}$

1939 In United States v. Miller, the US Supreme Court rules that the National Firearms Act of 1934 allows Congress to regulate the interstate selling of a short barrel shotgun, stating that the Second Amendment only prohibits laws which interfere with the "preservation or efficiency" of the states. ${ }^{8}$

1942 In Cases v. United States, the 1st Circuit Court upholds federal laws prohibiting possession of firearms by felons.?

1968 In Haynes $v$. United States, the US Supreme Court upholds Fifth Amendment precedents and rules that the registration requirement imposed on the possessor of an unregistered firearm by the NFA of 1934 violates the possessor's privilege from self-incrimination under the Fifth Amendment, rendering the NFA of 1934 unconstitutional. ${ }^{10}$

1968 Congress passes The Omnibus Crime Control and Safe Streets Act of 1968 following the assassination of President John F. Kennedy. Under this legislation, interstate trade in handguns is banned and the minimum age for buying handguns is raised to $21 .{ }^{11}$

1968 Congress passes the Gun Control Act (GCA) of 1968 following the assassinations of President John Kennedy, Attorney General Robert Kennedy, and Dr. Martin Luther King Jr. The law imposes stricter licensing and regulation on the firearms industry, names new categories of firearms offenses, and bans the sale of firearms and ammunition to felons and certain other prohibited persons. The law establishes the first federal jurisdiction over "destructive devices," including bombs, mines, grenades, and other similar mechanisms. The Treasury Department's Alcohol and Tobacco Tax Division is formed and given the power to enforce the Gun Control Act. $^{12}$

1971 In United States v. Bass, the US Supreme Court holds that the language of the Omnibus Crime Control and Safe Streets Act of 1968 does not specify whether a connection with interstate commerce must be made to individually prosecute a convicted felon for receiving or possessing a firearm. ${ }^{13}$
1971 In United States v. Decker, the 8th Circuit Court upholds extensive federal regulation of firearms dealers. ${ }^{14}$

1971 In United States v. Synnes, the 8th Circuit Court upholds federal laws prohibiting the possession of firearms by felons. $^{15}$

1972 The Alcohol and Tobacco Tax Division of the Internal Revenue Service becomes the Bureau of Alcohol, Tobacco and Firearms (ATF), an independent bureau. The ATF draws it jurisdictional powers from the Gun Control Act of 1968, Title VII of the Omnibus Crime Control and Safe Street Act of 1968, and Title XI of the Organized Crime Control Act of $1970 .{ }^{16}$

1972 In Cody v. United States, the 8th Circuit Court upholds the requirement that gun buyers accurately answer certain questions prior to purchase. ${ }^{17}$

1974 In United States v. Johnson, the 4th Circuit Court upholds federal laws prohibiting the possession of firearms by felons. ${ }^{18}$

1976 In Barrett v. United States, the US Supreme Court interprets the section of the Gun Control Act of 1968 that makes it illegal for a convicted felon "to receive any firearm or ammunition which has been shipped or transported in interstate or foreign commerce" to include the intrastate purchase of firearms by a felon from a gun seller of a firearm that previously, but without the felon's knowledge, had been transported across state lines from the manufacturer to a distributor and then to the seller. ${ }^{19}$

1976 In United States v. Warin, the 6th Circuit Court upholds federal laws banning machine guns and maintains that the Second Amendment confers a collective right, but not an individual right, to bear arms. ${ }^{20}$

1977 In Scarborough v. United States, the US Supreme Court rules that the Omnibus Crime Control and Safe Streets Act of 1968 makes it illegal for a felon to possess a firearm that had been sold across state lines even when the firearm has been purchased before the individual had become a convicted felon. ${ }^{21}$

1977 In United States v. Oakes, the 2nd Circuit Court upholds federal laws restricting the possession of machine guns. ${ }^{22}$

1982 In Quilici v. Village of Morton Grove, the 7th Circuit Court reaffirms the non-application of the Second Amendment to the states. ${ }^{23}$

1986 The Firearm Owners Protection Act (FOPA) expands the NFA definition of "silencer" to include combinations of parts for silencers and any parts that are used to make silencers and amended the GCA to ban machine gun ownership, except by government agencies and by 
owners who have legally bought their machine guns before May 19, 1986. ${ }^{24}$

1988 Congress passes the Undetectable Firearms Act, which makes it illegal to manufacture, import, sell, ship, deliver, own, transfer, or receive firearms containing less than 3.7 ounces of metal. ${ }^{25}$

1990 As part of the Crime Control Act of 1990, Congress passes the Gun-Free School Zones Act, which makes it a crime to possess or discharge a firearm in a school zone and outlaws the assembly of semiautomatic rifles or shotguns using legally imported parts. ${ }^{26}$

1992 In United States v. Hale, the 8th Circuit Court upholds federal laws regulating the private possession of machine guns. ${ }^{27}$

1993 The Brady Handgun Violence Prevention Act of 1993 amends the Gun Control Act of 1968 and imposes a waiting period of five days before a licensed importer, manufacturer, or dealer may sell, deliver, or transfer a handgun to an unlicensed individual. The waiting period applies only in states that do not have a solid system of background checks of potential gun buyers. ${ }^{28}$

1994 The Federal Assault Weapons Ban (AWB) is part of the Violent Crime Control and Law Enforcement Act of 1994 that bans the manufacture, transfer and possession of nineteen models of semiautomatic assault weapons and prohibits the transfer and possession of large capacity ammunition magazines that can hold more than ten rounds of ammunition. The AWB contains a sunset clause that ensures the semiautomatic assault weapons ban will expire ten years from the date of its enactment. ${ }^{29}$

1996 In Hickman v. Block, the 9th Circuit Court maintains the Second Amendment right is solely "held by the states." ${ }^{30}$

1996 In United States v. Rybar, the 3rd Circuit Court upholds federal laws regulating the private possession of machine guns. ${ }^{31}$

1996 In San Diego Gun Rights Comm. v. Reno, the 9th Circuit Court upholds the Federal Assault Weapons Ban. ${ }^{32}$

1997 In Printz v. United States, the US Supreme Court holds that certain temporary sections of the Brady Law violate the Tenth Amendment. In a concurring opinion, Justice Clarence Thomas suggests that the Second Amendment creates a "personal right to "keep and bear arms" and that such a right would preclude aggressive gun control regulations. ${ }^{33}$

1999 In Fraternal Order of Police v. United States, the DC Circuit Court upholds laws that make it illegal for persons convicted of domestic violence to own firearms. ${ }^{34}$
1999 In Gillespie v. City of Indianapolis, the 7th Circuit Court upholds a law prohibiting firearms ownership by persons subject to restraining orders. ${ }^{35}$

1999 In United States v. Baker, the 6th Circuit Court upholds federal laws prohibiting firearm possession by persons subject to domestic violence protection orders. ${ }^{36}$

1999 In United States v. Emerson, the Northern District of Texas US District Court strikes down a federal statute prohibiting the possession of firearms by persons subject to restraining orders, alluding to Thomas's opinion in Printz v. United States. ${ }^{37}$

1999 In United States v. Spruill, the Western District of Texas US District Court upholds federal laws prohibiting firearm possession by persons subject to restraining orders. ${ }^{38}$

2001 The Fifth Circuit Court of Appeals upholds the District Court's Ruling in United States $v$. Emerson, a ruling that the Supreme Court declines to review. ${ }^{39}$

2003 Backed by the National Rifle Association, the Tiahrt Amendments are provisions that have been attached to US Department of Justice appropriations bills since 2003 that significantly restrict law enforcement's ability to investigate gun crimes and prosecute dodgy gun dealers. The Amendments currently prevent the Alcohol, Tobacco and Firearms Bureau (ATF) from releasing firearm trace data to cities, states, researchers, litigants, and members of the public, require the FBI to destroy all approved gun buyer records within twenty-four hours, and bars the ATF from requiring gun dealers to submit their inventories to law enforcement. ${ }^{40}$

2005 The Protection of Lawful Commerce in Arms Act (PLCAA) protects firearms manufacturers and sellers from liability when crimes have been committed with their products. They can only be held liable if they sell a firearm to someone whom they know intends to use the firearm to commit a crime. The Child Safety Lock Act of 2005 (CLSA), Section 5 of the PLCAA, makes it illegal for licensed firearms dealers to sell handguns to any person, other than another licensee, unless the buyer is provided with a secure gun storage or safety device for that handgun. ${ }^{41}$

2007 After the Virginia Tech University shootings, the NICS Improvement Amendments Act (NIAA) is passed. The NIAA fixes loopholes in the National Instant Criminal Background Check (NICS) system, such as requiring state agencies to report persons with mental conditions that preclude them from legally purchasing firearms to the attorney general. ${ }^{42}$ 
2008 In District of Columbia v. Heller, the US Supreme Court reverses the precedent set by United States $v$. Miller in 1939 and rules that the Second Amendment confers an "individual right" to bear arms. The Court strikes down a District of Columbia law that banned virtually all handguns and required that other types of firearms in a home be dissembled or always equipped with a trigger lock. The Court maintains that handguns are the "most popular weapon chosen by Americans for self-defense in the home. ${ }^{.43}$

2010 In McDonald v. City of Chicago, the US Supreme Court rules that Second Amendment rights are applicable to states through the Fourteenth Amendment, affirming that state governments cannot infringe upon the individual's right to own firearms. ${ }^{44}$

2016 In Caetano v. Massachusetts, the US Supreme Court strikes down a ruling by a state court that upheld a ban on stun guns, stating that Second Amendment rights include owning firearms that were not in existence at the time the Constitution was written. ${ }^{45}$

2017 In Kolbe v. Hogan, the 4th Circuit Court upholds Maryland's assault weapons ban, ruling that the Firearms Safety Act enacted after the Sandy Hook Elementary shooting does not violate the Second Amendment. ${ }^{46}$

\section{Research Guide to the Second Amendment}

While the Second Amendment timeline recounts the official actions of our federal government, the debate surrounding those laws is complex. Government records are the best primary sources of this information, and many of those records are now digitized and can be found on government websites. Explore the following online government resources (and a few secondary sources) to find answers to such questions as, "Wasn't there a third part of the Second Amendment originally?," "What does the Fourteenth Amendment have to do with the Second Amendment?" (Hint: McDonald v. City of Chicago), and "What does it take for Congress to enact new firearms laws?" (Hint: think presidentially).

\section{Congress}

Congress.gov is the starting point for any federal legislative research. ${ }^{47} \mathrm{~A}$ source of congressional legislation, the site also offers access to the primary Founding Documents in one place, including an annotated version of the US Constitution, The Declaration of Independence, and the Bill of Rights. Among the Founding Documents included on Congress.gov are the Federalist Papers, eighty-five essays written by three of the Constitution's authorsAlexander Hamilton, James Madison, and John Jay-in favor of its ratification by the thirteen states. Federalist No. 29 by Alexander Hamilton (www.congress.gov/resources /display/content/The+Federa list+Papers\#TheFederalistPap

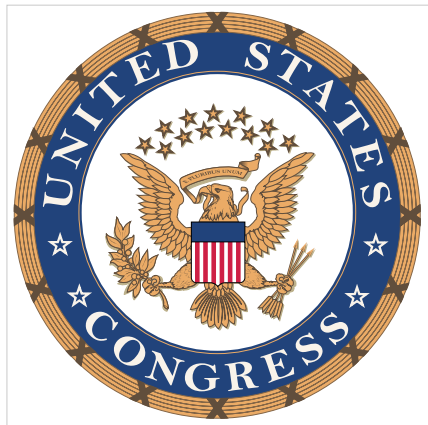
ers-29) and Federalist No. 46 by James Madison (www.congress.gov/resources/display/con tent/The+Federalist+Papers\#TheFederalistPapers-46) both discuss the notion of a well-regulated militia.

The Congressional Record at Congress.gov is published by the Government Publishing Office and reports the Congress' daily proceedings dating to 1995 . The index for the daily edition is published biweekly and is available on govinfo.gov dating back to 1983. The "History of Bills and Resolutions" for the daily edition of the Congressional Record is a separate collection in govinfo.gov and lists the House and Senate bills introduced in a congressional session and summarizes their legislative history.

The United States Congressional Serial Set Catalog within the Catalog of U.S. Government Publications (catalog.gpo.gov) contains records for House and Senate reports, House and Senate documents, Senate executive reports and documents, and Senate treaty documents.

The Library of Congress (LOC) at loc.gov, the research arm of Congress, holds a digital collection of early historical legislative documents on its website at "A Century of Lawmaking for a New Nation, US Congressional Documents and Debates 17741875. ${ }^{\text {,48 }}$ The LOC also has webpages devoted to the Second Amendment. Start with the research guide entitled "United States: Gun Ownership and the Supreme Court" ${ }^{\text {׳49 }}$ and then Ruth Levush's "Firearms-Control Legislation and Policy." 50

The U.S. Code at uscode.house.gov is "an official consolidation and codification by subject matter of the general and permanent laws of the United States." ${ }^{\text {11 }}$ Search the U.S. Code for codified versions of the National Firearms Act and the Gun Control Act. The Law Library of Congress (loc.gov/law) has digitized the United States Statutes at Large from 1789 to present. Reading the Statutes in their chronological order makes it easier to follow the evolution of the laws before they are codified into the U.S. Code.

House.gov, the portal to the US House of Representatives, has an organizational chart of the House, an index of congress persons with contact information, the House Leadership, and current legislative work. ${ }^{52}$ Current House Bills pertaining to the 
Second Amendment can be tracked here. Similarly, Senate.gov offers access to and information about the US Senate. ${ }^{53}$

The Congressional Research Service (CRS) consists of subject matter experts at the Library of Congress who prepare confidential, nonpartisan, factual reports for member of Congress about public policy. CRS reports such as "Gun Control: Statutory Disclosure Limitations on ATF Firearms Trace Data and Multiple Handgun Sales Reports" by William J. Krouse are solid resources but have not been readily found on government sites. Recently, Congress passed a law to place CRS reports under the umbrella of the Federal Depository Library Program. The Librarian of Congress has been directed to make all CRS reports equally accessible online. ${ }^{54}$ Until that public website is ready, here are a few free online sites to find CRS reports:

- Archive-It.org

- CRSreports.com

- EveryCRSReport.com

- Federation of American Scientists (fas.org)

\section{The Courts}

At SupremeCourt.gov you can find Opinions of the Court, which are collected in sets of books called reporters. ${ }^{55}$ The United States Reports is the official edition, and digital bound versions can be found on the US Supreme Court's website. The bound volumes

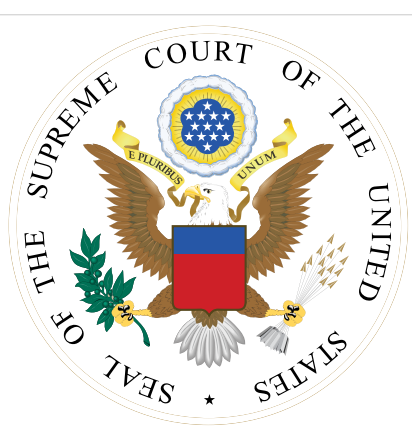
from number 502 forward and date from the October term of 1991 are published on the site. The Court's latest Slip Opinions that have yet to be bound are also available on the site. Use the advanced search option to find Court opinions but read the search tips first.

If searching for Court opinions on SupremeCourt.gov frustrates you, Google Scholar (scholar.google.com) makes its exhaustive collection of case law more easily searchable. Mark the "Case Law" button to search for US Supreme Court cases since 1791, Federal District Courts and Appellate Courts cases from 1923 and State Supreme Courts and State Appellate Courts cases from 1950.

Other free, solid resources for case law are Findlaw.com, where you can find Supreme Court Briefs from October 1999 to 2007, Cornell Law School's Legal Institute (www.law.cornell .edu/), and Oyez.org, a complete multimedia judicial archive of the U.S Supreme Court and source for all the Court's audio since October 1955. Listen to the Court's announcement of its opinion in District of Columbia v. Heller at www.oyez.org /cases/2007/07-290.

\section{The Executive Branch}

Three Federal agencies are tasked with the job of implementing firearms laws and are appropriately under the umbrella of the US Department of Justice. ${ }^{56}$ The Bureau of Alcohol, Tobacco, Firearms and Explosives is the starting point for exploring the Sec-

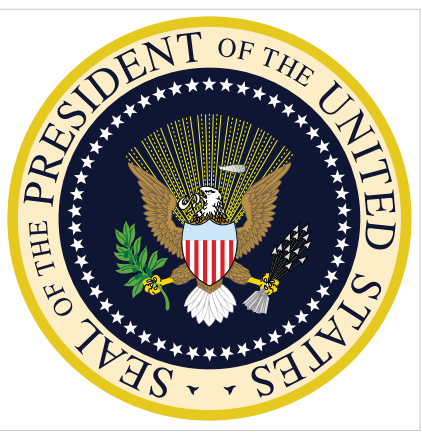
ond Amendment within the executive branch, as the ATF owes its existence to firearms legislation. Central to the ATF's mission is the protection of the public from crimes involving firearms, explosives, arson, the diversion of alcohol and tobacco products, and to regulate lawful commerce in firearms and explosives. ${ }^{57}$ The ATF issues rules and regulations that put the NFA and the GCA into effect, which can be found at atf.gov/rules-and-regulations/firearms -rulings. One of the ATF's tools is the National Tracing Center (NTC), the sole organization authorized to trace US and foreign manufactured firearms for international, federal, state, and local law enforcement agencies. ${ }^{58}$

The Bureau of Justice Statistics (bjs.gov) bills itself as the United States' primary source for criminal justice statistics. Browse its site by the topic of "Crime Type," then look at "Weapon Use" to find reports like Firearm Violence, 1993-2011 by Michael Planty and Jennifer L. Truman, where you might be surprised to find the table 1, "Criminal Firearm Violence, 1993-2011."60

The Federal Bureau of Investigations (fbi.gov) is mandated by the Brady Handgun Violence Prevention Act of 1993 to run the National Instant Criminal Background Check System that is used by licensed firearms dealers to instantly determine whether a prospective buyer can legally buy firearms. ${ }^{61}$

The Federal Register (federalregister.gov) is the official journal of the federal government and holds government agency rules, proposed rules, and public notices. Public notices are meant to inform citizens of impending regulations and offer them a timeframe to provide comments to the agencies who are proposing the regulations. The Federal Register is updated every business day, and the final rules issued by the federal agencies and published in the Federal Register are collected and codified in the Code of Federal Regulations (CFR), which is updated annually. 
TABLE 1

Criminal firearm violence, 1993-2011

\begin{tabular}{|c|c|c|c|c|c|c|c|}
\hline \multirow[b]{2}{*}{ Year } & \multirow[b]{2}{*}{$\begin{array}{l}\text { Total fatal and nonfatal } \\
\text { firearm violence }\end{array}$} & \multicolumn{3}{|c|}{ Number } & \multirow[b]{2}{*}{$\begin{array}{l}\text { Rate of nonfatal } \\
\text { firearm victimizationc }\end{array}$} & \multicolumn{2}{|c|}{ Percent } \\
\hline & & $\begin{array}{l}\text { Firearm } \\
\text { homicides }\end{array}$ & $\begin{array}{l}\text { Nonfatal firearm } \\
\text { victimizations }^{\mathrm{a}}\end{array}$ & $\begin{array}{l}\text { Nonfatal firearm } \\
\text { incidents }\end{array}$ & & $\begin{array}{l}\text { All violence } \\
\text { involving firearms }\end{array}$ & $\begin{array}{l}\text { All firearm violence } \\
\text { that was homicide }\end{array}$ \\
\hline 1993 & $1,548,000$ & 18,253 & $1,529,700$ & $1,222,700$ & 7.3 & $9.2 \%$ & $1.2 \%$ \\
\hline 1994 & $1,585,700$ & 17,527 & $1,568,200$ & $1,287,200$ & 7.4 & 9.3 & 1.1 \\
\hline 1995 & $1,208,800$ & 15,551 & $1,193,200$ & $1,028,900$ & 5.5 & 7.9 & 1.3 \\
\hline 1996 & $1,114,800$ & 14,037 & $1,100,800$ & 939,500 & 5.1 & 7.9 & 1.3 \\
\hline 1997 & $1,037,300$ & 13,252 & $1,024,100$ & 882,900 & 4.7 & 7.7 & 1.3 \\
\hline 1998 & 847,200 & 11,798 & 835,400 & 673,300 & 3.8 & 7.0 & 1.4 \\
\hline 1999 & 651,700 & 10,828 & 640,900 & 523,600 & 2.9 & 6.1 & 1.7 \\
\hline 2000 & 621,000 & 10,801 & 610,200 & 483,700 & 2.7 & 7.3 & 1.7 \\
\hline 2001 & 574,500 & 11,348 & 563,100 & 507,000 & 2.5 & 7.7 & 2.0 \\
\hline 2002 & 551,800 & 11,829 & 540,000 & 450,800 & 2.3 & 7.4 & 2.1 \\
\hline 2003 & 479,300 & 11,920 & 467,300 & 385,000 & 2.0 & 6.2 & 2.5 \\
\hline 2004 & 468,100 & 11,624 & 456,500 & 405,800 & 1.9 & 6.9 & 2.5 \\
\hline 2005 & 515,900 & 12,352 & 503,500 & 446,400 & 2.1 & 7.4 & 2.4 \\
\hline 2006 & 627,200 & 12,791 & 614,400 & 552,000 & 2.5 & 7.4 & 2.0 \\
\hline 2007 & 567,400 & 12,632 & 554,800 & 448,400 & 2.2 & 8.3 & 2.2 \\
\hline 2008 & 383,500 & 12,179 & 371,300 & 331,600 & 1.5 & 6.0 & 3.2 \\
\hline 2009 & 421,600 & 11,493 & 410,100 & 383,400 & 1.6 & 7.4 & 2.7 \\
\hline 2010 & 426,100 & 11,078 & 415,000 & 378,800 & 1.6 & 8.6 & 2.6 \\
\hline $2011^{d}$ & 478,400 & 11,101 & 467,300 & 414,600 & 1.8 & 8.2 & 2.3 \\
\hline
\end{tabular}

Note: See appendix table 3 for standard errors.

${ }^{\text {aA }}$ victimization refers to a single victim that experienced a criminal incident.

${ }^{\mathrm{b}} \mathrm{An}$ incident is a specific criminal act involving one or more victims or victimizations.

CPer 1,000 persons age 12 or older.

dPreliminary homicide estimates retrieved from Hoyert DL, Xu JQ. (2012) Deaths: Preliminary data for 2011. National Vital Statistics Reports, 61(6).

Sources: Bureau of Justice Statistics, National Crime Victimization Survey, 1993-2011; and Centers for Disease Control and Prevention, National Center for Injury Prevention and Control, Web-based Injury Statistics Query and Reporting System (WISQARS), 1993-2010. Retrieved March 2013 from www.cdc.gov/ncipc/wisqars.

Search the Federal Register website for rules and regulations that have been generated since 1994 to implement the NFA and the GCA. For a full listing of federal regulations browse govinfo.gov. You will find a recently repealed Social Security Administration (SSA) rule that states the SSA's plan to report mentally-challenged disability recipients who could not take care of their affairs to the NICS system at www.federalregister .gov/documents/2016/12/19/2016-30407/implementation-of -the-nics-improvement-amendments-act-of-2007.

Science.gov is a federal public access portal that offers free access to research and development results and scientific and technical information from scientific organizations across thirteen federal agencies and is a solid source of statistical reports and analysis of firearm violence in the US and other countries. ${ }^{62}$ Science.gov includes reports such as the CRS report "Mass Murder with Firearms: Incidents and Victims, 1999-2013" by William J. Krouse and Daniel J. Richardson with charts like figure $1 .^{63}$

\section{One Stop Shopping}

These are official online sources of federal government information and documents for all three branches: ${ }^{64}$
- Govinfo.gov is the US citizens' official guide to federal government and a service of the United States Government Publishing Office (GPO). Govinfo.gov is "free U.S. Government information for

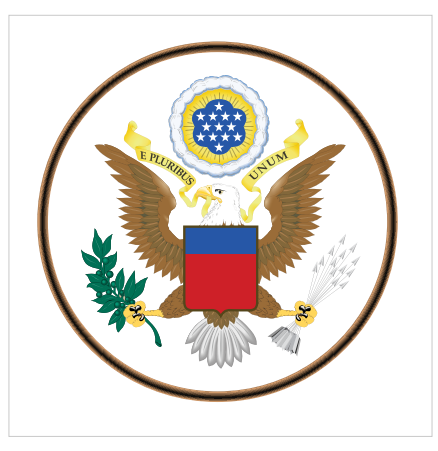
all" and offers "free access to official publications." ${ }^{\text {"65 }}$

- The Catalog of U.S. Government Publications (CGP) at catalog.cgp.gov is the finding tool for federal government publications, which comprise the National Bibliography of U.S. Government Publications. "The CGP contains descriptive records for historical and current publications and provides direct links to those that are available online." ${ }^{\prime 66}$ To find publications issued prior to 1976, check the printed Monthly Catalog at a Federal Depository Library or log onto WorldCat .org, a global collection of library collections, as several 


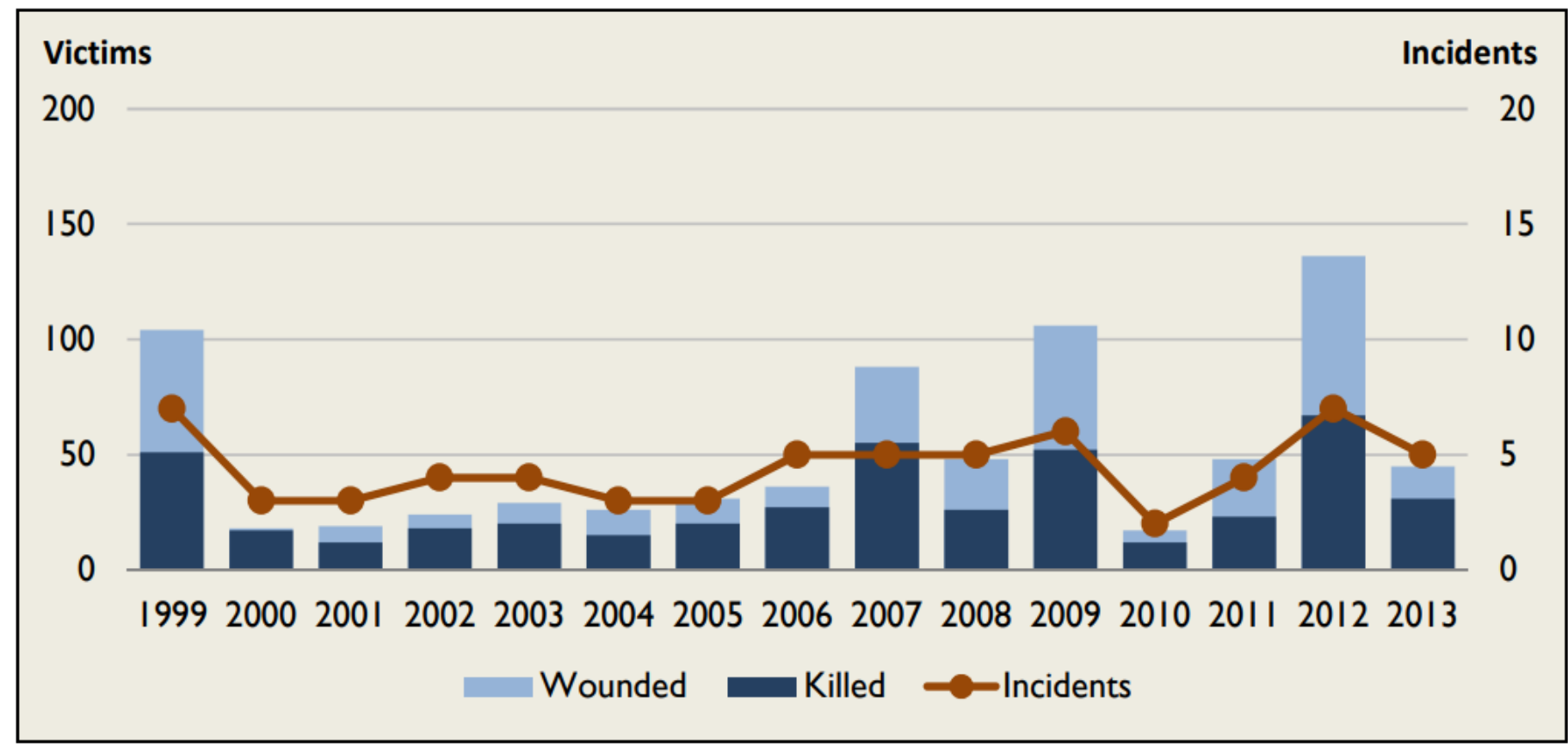

Source: CRS analysis of FBI Supplementary Homicide Reports, press accounts, agency press releases, and other compilations by mass media and advocacy groups.

Notes: "Mass public shooting" means a multiple homicide incident in which four or more victims are murdered with firearms-not including the offender(s) - within one event, and at least some of the murders occurred in a public location or locations in close geographical proximity (e.g., a workplace, school, restaurant, or other public settings), and the murders are not attributable to any other underlying criminal activity or commonplace circumstance (armed robbery, criminal competition, insurance fraud, argument, or romantic triangle).

Figure 1. Mass Public Shootings at Workplace, Schools, Restaurants, and Other Public Places (1999-2013)

Federal Depository Libraries have cataloged their complete depository holdings.

- The US Government Publishing Office (GPO) at gpo .gov keeps US citizens informed "as the official, digital, and secure source for producing, preserving, and distributing official Federal Government publications and information products for Congress, Federal agencies, and the American public." ${ }^{\text {67 }}$ Scroll to the bottom of their home page to find links to other federal resources.

- USA.gov is the official portal to the federal government and state, local, and tribal governments as well. Its mission is to "create and organize timely, needed government information and services and make them accessible. $^{.68}$

Hopefully, this guide serves its purpose to inform and engage citizens in the debate surrounding the Second Amendment. The evolution of the interpretation of the Second Amendment from conferring a collective right held by the states to bestowing an individual right upon all Americans is revealed by the documents the federal government has generated. Citizens have only to read them for themselves. No guide is complete, however, and for further research you should contact your local Federal Depository Librarian.

D. L.Womble (womble56@uw.edu), MLIS Candidate, University of Washington LIS526 Government Publications

\section{References}

1. The Constitution of the United States of America (With Analysis), S.Doc. 112-9, (2017) www.govinfo.gov/app /details/GPO-CONAN-2017/GPO-CONAN-2017-9.

2. United States v. Cruikshank, 92 U.S. 542 (1876).

3. Presser v. Illinois, 116 U.S. 252 (1886).

4. Miller v. Texas, 153 U.S. 535 (1894).

5. Robertson v. Baldwin, 165 U.S. 275 (1897). 
6. National Firearms Act of 1934, Pub. L No. 73-474, 48 Stat.1236 (1934), www.loc.gov/law/help/statutes-at-large 173rd-congress/session-2/c73s2ch757.pdf.

7. Federal Firearms Act of 1938, Pub. L No. 75-785, 52 Stat.1250 (1938), www.loc.gov/law/help/statutes-at-large 175th-congress/session-3/c75s3ch850.pdf.

8. United States v. Miller, 307 U.S. 174 (1939).

9. Cases v. United States, 131 F.2d 916 (Court of Appeals, 1st Circuit 1942).

10. Haynes v. United States, 390 U.S. 85 (1968).

11. Omnibus Crime Control and Safe Streets Act of 1968, Pub. L No. 90-351, 82 Stat. 197 (1968), www.govinfo .gov/content/pkg/STATUTE-82/pdf/STATUTE-82 -Pg197.pdf.

12. Gun Control Act of 1968, Pub. L No. 90-618, 82 Stat. 1213-2 (1968), www.govinfo.gov/content/pkg/STATUTE -82/pdf/STATUTE-82-Pg1213-2.pdf.

13. United States v. Bass, 404 U.S. 336 (1971).

14. United States v. Decker, 446 F 2d 164 (Court of Appeals, 8th Circuit 1971).

15. United States v. Synnes, 438 F.2d 764 (Court of Appeals, 8th Circuit 1971).

16. "Treasury Department Order 221," Bureau of Alcohol, Tobacco, Firearms and Explosives, www.atf.gov/our -history/timeline/treasury-department-order-221.

17. Cody v. United States, 460 F. 2d 34 (Court of Appeals, 8th Circuit 1971).

18. United States v. Johnson, 497 F. 2d 548 (Court of Appeals, 4th Circuit 1974).

19. Barrett v. United States, 423 U.S. 212 (1975).

20. United States v. Warin, 530 F. 2d 103 (Court of Appeals, 6th Circuit 1976).

21. Scarborough v. United States, 431 U.S. 563 (1977).

22. United States v. Oakes, 564 F.2d 384 (Court of Appeals, 10th Circuit 1977).

23. Quilici v. Village of Morton Grove, 695 F.2d 261 (Court of Appeals, 7th Circuit 1982).

24. Firearm Owners Protection Act of 1986, 18 U.S.C. $\$$ 926A (2016), www.govinfo.gov/content/pkg/USCODE -2015-title18/pdf/USCODE-2015-title18-partI-chap44 -sec926A.pdf.

25. Undetected Firearms Act of 1988, Pub. L. No. 100-649, 102 Stat. 3816 (1988), https://www.govinfo.gov/content /pkg/STATUTE-102/pdf/STATUTE-102-Pg3816.pdf.

26. Crime Control Act of 1990, Pub. L. No. 101-647, 104 Stat. 4789 (1990), www.govinfo.gov/content/pkg/STAT UTE-104/pdf/STATUTE-104-Pg4789.pdf.
27. United States v. Hale, 978 F.2d 1016 (Court of Appeals, 8th Circuit 1992).

28. Brady Handgun Violence Prevention Act of 1993, Pub. L. No. 103-159, 107 Stat. 1536 (1993), www.govinfo.gov /content/pkg/STATUTE-107/pdf/STATUTE-107 -Pg1536.pdf.

29. Violent Crime Control and Law Enforcement Act of 1994, Pub. L. No. 103-322, 108 Stat. 1796 (1994), www .govinfo.gov/content/pkg/STATUTE-108/pdf/STAT UTE-108-Pg1796.pdf.

30. Hickman v. Block, 81 F.3d 98 (Court of Appeals, 9th Circuit 1996).

31. United States v. Rybar, 103 F.3d 273 (Court of Appeals, 3rd Circuit 1995).

32. San Diego County Gun Rights v. Reno, 98 F.3d 1121 (Court of Appeals, 9th Circuit 1996).

33. Printz v. United States, 521 U.S. 898 (1997).

34. Fraternal Order of Police v. United States, 152 F.3d 998 (Court of Appeals, Dist. of Columbia Circuit 1998).

35. Gillespie v. City of Indianapolis, 185 F.3d 693 (Court of Appeals, 7th Circuit 1999).

36. United States v. Baker, 197 F.3d 211 (Court of Appeals, 6th Circuit 1999).

37. United States v. Emerson, 46 F. Supp. 2d 598 (N.D. Tex. 1999).

38. United States v. Spruill, 61 F. Supp. 2d 587 (W.D. Tex. 1999).

39. United States v. Emerson, 270 F.3d 203 (Court of Appeals, 5th Circuit 2001).

40. William J. Krouse, Gun Control: Statutory Disclosure Limitations on ATF Firearms Trace Data and Multiple Handgun Sales Reports, RS 22458 (Washington DC: Congressional Research Service, 2009), fas.org/sgp/crs /misc/RS22458.pdf.

41. Protection of Lawful Commerce in Arms Act of 2005, Pub. L. No.109-92, 119 Stat. 2095 (2005), www.gov info.gov/content/pkg/STATUTE-119/pdf/STATUTE -119-Pg2095.pdf.

42. NICS Improvement Amendments Act of 2007, Pub. L. No.110-180, 121 Stat. 2559 (2007), www.govinfo .gov/content/pkg/STATUTE-121/pdf/STATUTE -121-Pg2559.pdf.

43. District of Columbia v. Heller, 554 U.S. 570 (2008).

44. McDonald v. City of Chicago, Ill., 561 U.S. 742 (2010).

45. Caetano v. Massachusetts, 136 S.Ct. 1027 (2016)

46. Kolbe v. Hogan, 849 F. 3d 114 (Court of Appeals, 4th Circuit 2016). 
47. US Congressional seal: Ipankonin, Unofficial Seal of the United States Congress, Public Domain, commons.wiki media.org/wiki/File:Seal_of_the_United_States_Con gress.svg.

48. "A Century of Lawmaking for a New Nation: U.S. Congressional Documents and Debates, 1774-1875," Library of Congress, memory.loc.gov/ammem/amlaw/lawhome .html.

49. "Second Amendment," Law Library of Congress, loc.gov /law/help/second-amendment.php.

50. Ruth Buchanan Levush, Firearms-Control Legislation and Policy, www.loc.gov/law/help/firearms-control/index.php.

51. "United States Code," US House of Representatives, uscode. house. gov/browse. $x$ html;jsessionid=3136D1F7C F8A3A5A0DBF45AE9E4D9A91.

52. "Home," US House of Representatives, www.house.gov/.

53. "U.S. Senate," US Senate, www.senate.gov/.

54. "CRS Reports in Scope of the FDLP," Government Publishing Office, www.fdlp.gov/news-and-events/3396 -crs-reports-in-scope-of-the-fdlp.

55. US Supreme Cout seal: Optimager, Own work based on: Seal of the United States Supreme Court.png by Optimager. This seal includes elements that have been taken or adapted from this seal: US-GreatSeal-Obverse.svg (by Ssolbergj), Public Domain, commons.wikimedia.org /w/index.php?curid $=1831846$.

56. US Presidential seal: Unknown-Extracted from the title page of PDF document at www.whitehouse.gov/nsc/nss .pdf, Public Domain, commons.wikimedia.org/w/index .php?curid=903036.

57. "About," Bureau of Alcohol, Tobacco, Firearms and Explosives, www.atf.gov/about.
58. "National Tracing Center," Bureau of Alcohol, Tobacco, Firearms and Explosives, www.atf.gov/firearms/national -tracing-center.

59. "About the Bureau of Justice Statistics," Bureau of Justice Statistics, www.bjs.gov/index.cfm?ty=abu.

60. Michael Planty and Jennifer Truman, Firearm Violence, 1993-2011, 2013, 28, www.bjs.gov/content/pub/pdf/fv9 311.pdf.

61. Federal Bureau of Investigation, National Instant Criminal Background Check System (NICS), Folder, accessed August 23, 2018, https://www.fbi.gov/services/cjis/nics.

62. "Science.Gov: About," www.science.gov/about.html.

63. William J. Krouse and Daniel J. Richardson, Mass Murder with Firearms: Incidents and Victims, 1999-2013, Congressional Research Service, ntrl.ntis.gov/NTRL /dashboard/searchResults/titleDetail/PB2016101105 .xhtml.

64. US Government seal: US Government, Obverse of Great Seal of the United States, Public Domain, commons .wikimedia.org/wiki/File:Great_Seal_of_the_United_ States_(obverse).svg.

65. "About Us | govinfo," Government Publishing Office, www.govinfo.gov/about.

66. "Entire CGP Catalog_About," Government Publishing Office, catalog.gpo.gov/F/T1SH6FNS11HPDAGL 2RLSSKLREN1Y32TLS1D9PJK9DY6TC5QTMV -00282 ? func $=$ file $\&$ file_name $=$ about - gpo $01 \&$ local_ base $=$ GPO01PUB .

67. "Mission,Vision, andGoals,"GovernmentPublishingOffice, www.gpo.gov/who-we-are/our-agency/mission-vision -and-goals.

68. "About USA.Gov," www.usa.gov/about. 